\title{
Anne-Bebek Bağlanmasının Annelik Algısı ve Bazı Değişkenlere Göre İncelenmesi
}

\author{
The Investigation of Mother-Baby Attachment Based on Maternal Perception and Some
} Variables

\author{
Nida ENGİN ${ }^{1 \text { A,B,C,D,E,F,G@, Tülay KUZLU AYYILDIZ }}{ }^{2}$ A,B,C,D,F,G@ \\ ${ }^{1}$ Samsun Sağllk Bilimleri Üniversitesi Eğitim ve Araştırma Hastanesi, Samsun, Türkiye \\ ${ }^{2}$ Zonguldak Bülent Ecevit Üniversitesi Sağlık Bilimleri Fakültesi Hemşirelik Bölümü, Zonguldak, Türkiye
}

ÖZ

\begin{abstract}
Amaç: Bu çalışma, anne-bebek bağlanmasının annelik algısı ve bazı değişkenlere göre incelenmesi amacıyla yapılmıştır. Yöntem: Çalışmanın örneklemini Aralık 2019-Haziran 2020 tarihleri arasında Zonguldak il merkezinde bulunan iki hastanenin kadın doğum kliniklerinde doğum yapmış olan ve araştırmaya katılmayı kabul eden 368 anne oluşturmuştur. Verilerin toplanmasında "Anne-Bebek Tanıtıcı Bilgi Formu", "Anne-Bebek Bağlanma Ölçeği”, "Çok Boyutlu Algılanan Sosyal Destek Ölçeği”" ve "Anlamsal Farklılık Ölçeği (Anne Olarak Ben ve Bebeğim)" formları kullanılmıștır. Verilerin analizinde SPSS 22.0 ve AMOS 21.0 paket programları kullanılmıştır.

Bulgular: Araştırmaya katılan annelerin, anne-bebek bağlanma düzeyi ortalamasııın 22.25 2.01 (17-24) arasında değiştiği belirlenmiştir. Çalışmada anne-bebek bağlanmasının annenin eğitim, sosyal güvenceye sahip olma ve gelir durumu, aile tipi, evlilik-gebeliğin isteğe bağlı olması, doğum öncesi bakım eğitimi alma, doğum şekli, canlı doğum sayısı, bebeğin kucaklanma, ilk emzirilme zamanı ve beslenme türüne göre farklılaştı̆̆ saptanmıștır $(\mathrm{p}<0.005)$.

Sonuç: Sosyal destek, annelik algısı ve bebeğim algısı faktörlerinin anne-bebek bağlanmasına etkisi \%42 olarak tespit edilmiştir.
\end{abstract}

Anahtar Kelimeler: Anne-bebek bağlanması, Annelik algısı, Bebeğim algısı, Sosyal destek algısı, Hemşirelik.

\section{ABSTRACT}

Objective: The aim of the study was to examine mother-infant attachment based on the perception of motherhood and some variables.

Methods: The sample of the study included 368 mothers who gave birth in the obstetrics clinics of two hospitals in Zonguldak between December 2019 and June 2020 and who agreed to participate in the study. Data were collected using a "Mother-Baby Information Form", the "Maternal Attachment Inventory", "Multi-Dimensional Scale of Perceived Social Support" and "Semantic Differential Scale (Myself as a Mother and My Baby)". The data were analyzed using SPSS 22.0 and AMOS 21.0 programs.

Results: It was found that the mean mother-infant attachment level of the mothers in this study changed between $22.25 \pm 2.01$ (17-24). It was found that mother-infant attachment changed based on the mother's education level, having social insurance, income level, family type, intended marriage and pregnancy, receiving care training, delivery mode, the numbers of birth, hugging the baby, time of first breastfeeding and type of nutrition $(\mathrm{p}<0.005)$.

Conclusion: The factors of social support, perception of motherhood, and the perception of my baby have a $42 \%$ influence on mother-infant attachment.

Keywords: Mother-infant attachment, Maternal perception, My baby perception, Social support perception, Nursing.

Sorumlu Yazar:Nida ENGIN

Samsun Sağlık Bilimleri Üniversitesi Eğitim ve Araştırma Hastanesi, Samsun, Türkiye

d.nida54@gmail.com

Geliş Tarihi: 02.06.2021 - Kabul Tarihi: 11.08.2021

Yazar Katkıları: A)Fikir/Kavram, B) Tasarım, C) Veri Toplama ve/veya İșleme, D) Analiz ve/veya Yorum, E) Literatür

Taraması, F) Makale Yazımı, G) Eleştirel İnceleme 


\section{GİRİş}

Bağlanma; yaşam için gerekli olan, bebek ile birincil bakım veren arasında gelişen, birçok faktörden etkilenen, bebekte güven duygusunu oluşturan güçlü bir bağdır $(1,2)$. Annebebek bağlanması; davranışsal ve duygusal düzeyde, gebenin bedeninde değişiklikler oldukça, uterusu genişledikçe ve annenin fetal hareketleri hissetmeye başlamasıyla artarak güçlenen annenin bebeğine karşı olan bağlanma durumudur. Anne ile bebeği arasında güçlü bir bağın oluşması bebeğin bakımının sağlanabilmesi için gereklidir. Anne bebek bağlanması arttıkça anne tüm dikkati bebeğine yöneltir $(3,4)$.

Güçlü anne bebek bağlanması gebelik sürecinden başlayarak anneyi, sağlıklı uyku, beslenme, egzersiz alışkanlıkları, alkol madde kullanımından kaçınma, düzenli sağlık kontrollerini yaptırma gibi bebeğin sağlığını korumaya yönelik uygulamalara motive eder; annenin annelik rolüne uyumunu kolaylaştırır ve doğum sonu depresyonu azaltır (5). Annenin bebeğine karşı gösterdiği olumsuz bağlanma davranışları ise, bebekte huzursuzluk, ağlama nöbetleri, uyku sorunları, beslenme bozukluğu, büyüme-gelişme geriliği, ihmal, istismar gibi sorunların yaşanmasına neden olabilmektedir $(6,7)$.

Kadınların gebelik boyunca annelik rolünü benimsemesi, doğum sonrası erken ve geç dönemde, bağlanma davranışları ve bebek bağlanma örüntüleri için oldukça önemlidir (8). Aynı zamanda gebelik ve doğum sonrası dönemde, anne ya da bebeğe ait bazı faktörler anne-bebek bağlanmasını etkileyebilmektedir (9). Annenin yaşı, gebeliğin istenme durumu, çocuk sayısı, ailenin sosyo-ekonomik durumu, annenin algıladığı sosyal destek, eş ile ilişki ve eş desteği gibi anneye ait faktörlerin yanında cinsiyet, sağlık sorunları, doğum sırası gibi yeni doğana ait bazı faktörlerden de anne bebek bağlanmasının etkilediği bildirilmektedir (10). Anne ve bebek arasındaki bağın oluşmasında, doğumdan sonra erken dönemde emzirmeye başlanılması, anne ile bebeğin aynı odayı paylaşması, annenin bebeği ile erken dönemde iletişime geçmesi, kucağına almasının da bağlanma sürecini hızlandırabildiği bilinmektedir $(4,5)$.

Güçlü ve sağlıklı anne-bebek bağlanması için; anne-bebek bağlanmasını etkileyen faktörlerin bilinmesi önemlidir. Bu amaçla bu araştırma annelerde, anne bebek bağlanmasının annelik algısı ve bazı değişkenlere göre incelenmesi amacıyla yapılmıştır. Araştırma soruları;

1. Anne-bebek bağlanma düzeyini anneye ait bazı özellikler etkiler mi?

2. Anne-bebek bağlanma düzeyini bebeğe ait bazı özellikler etkiler mi?

3. Anne-bebek bağlanma düzeyi annelik algısından etkilenir mi?

4. Anne-bebek bağlanma düzeyi algılanan sosyal destek düzeyi etkilenir mi?

5. Anne-bebek bağlanması annelik algısı ve algılanan sosyal destek arasındaki ilişkinin düzeyi nedir?

\section{GEREÇ VE YÖNTEMLER}

\section{Araştırmanın Amacı ve Tipi}

Tanımlayıcı ilişki arayıcı türde yapılmıştır.

\section{Araştırmanın Yapıldığı Yer, Zaman ve Örneklemi}

Araştırmanın evrenini Zonguldak il merkezinde bulunan bir devlet hastanesi ve üniversite hastanesinin kadın doğum servislerinde 1 Ocak 2019-31 Aralık 2019 tarihleri arasında canlı doğum yapan anneler oluşturmuştur $(\mathrm{N}=2300)$. Örneklem sayısı evren bilindiği 
durumlarda kullanılan formüle göre minimum 340 olarak hesaplanmıştır. Araştırmanın örneklemini Aralık 2019-Haziran 2020 tarihleri arasında Zonguldak il merkezinde bulunan iki hastanenin kadın doğum kliniklerinde doğum yapmış olan anneler oluşturmuştur. Hastanelerde gerçekleşen doğum sayısına göre tabakalandırma yapılarak, üniversite hastanesinde $(n=178)$ ve kadın doğum ve çocuk hastalıkları hastanesinde $(n=190)$ kadın doğum kliniklerinde doğum yapmış olan, okuma-yazma bilen, görme, işitme ve mental problemi olmayan, Türkçe bilen ve araştırmaya katılmayı kabul eden 368 anne örneklemi oluşturmuştur.

\section{Etik Yaklaşım}

Araştırmanın yapılabilmesi için gerekli etik kurul (27.06.2019-611) ve kurumlardan yazılı izinler alınmıştır. Araştırmaya katılan annelerden yazılı onam alınmıştır. Ölçeklerin araştırmada kullanılabilmesi için, ölçek yazarlarından elektronik posta yoluyla izin alınmıştır.

\section{Veri Toplama Araçları}

Anne-Bebek Tanıtıcı Bilgi Formu; Literatür bilgisi 1şığında oluşturulan bu formda anneye, doğurganlığa ve bebeğe ait tanımlayıcı özellikleri içeren ve kategorik değişkenlerden oluşan toplamda 40 adet madde yer almaktadır (11-13).

\section{Anne-Bebek Bağlanma Ölçeği}

Anne tarafından doldurulan ölçek, doğum sonrası annenin bebeğine karşı hissettiği duygusal durumları içeren sekiz maddeden oluşmaktadır. Ölçek maddeleri, “(0) Çok fazla” ile “(3) Hiçbir zaman” olmak üzere dörtlü Likert tipi derecelendirmeden oluşmaktadır. Yüksek puan anne ile bebeğin bağlanma sorunu olduğunu gösterir. Ölçeğin geçerlilik güvenilirlik çalışmasında Cronbach alfa değeri 0.66-0.69 olarak bildirmiştir (12). Ölçeğin bu araştırmadaki Cronbach Alfa iç tutarlılık katsayısı ise 0.80 olarak bulunmuştur. Ölçeğin bu araştırmadaki yapısal geçerliliğinin belirlenmesi için doğrulayıcı faktör analizi kullanılmıştır. Uyum iyiliği değerleri ( $(\mathrm{N}=368$ için; $\chi 2 / \mathrm{Sd}=3.798 ; \mathrm{GFI}=0.967$; $\mathrm{CFI}=0.965 ; \mathrm{TLI}=0.929 ; \mathrm{RMSEA}=0,08)$ ölçeğin yapısal geçerliliğinin kabul edilebilir düzeyde olduğunu göstermektedir (14).

\section{Çok Boyutlu Algılanan Sosyal Destek Ölçeği}

Ölçek yedi dereceli olarak düzenlenmiş, 12 madden oluşan "Kesinlikle hayır 1.2.3.4.5.6.7. Kesinlikle evet" şeklinde düzenlenmiş likert tipi bir ölçektir. Ölçek, destek kaynaklarını yansıtan aile, arkadaş, özel destek olmak üzere üç alt gruptan oluşmaktadır ve her grupta da dört madde bulunmaktadır. Ölçekteki puanın fazla olması, algılanan sosyal desteğin de fazla olduğunu belirtmektedir. Ölçeğin geçerlilik güvenilirlik çalışmasında Cronbach Alfa iç tutarlılık katsayısı aile alt boyutu için 0.85 ; arkadaş alt boyutu için 0.88 ; özel insan alt boyutu için 0.92 ve tüm ölçek için ise 0.89 olarak bildirilmiştir (15). Ölçeğin bu araştırmadaki Cronbach Alfa iç tutarlılık katsayısı aile alt boyutu için 0.99; arkadaş alt boyutu için 0.99; özel insan alt boyutu için 0.99 ve tüm ölçek için ise 0.98 olarak bulunmuştur. Uyum iyiliği değerleri $((\mathrm{N}=368$ için; $\chi 2 / \mathrm{Sd}=3.936 ; \mathrm{GFI}=0.924 ; \mathrm{CFI}=0.987 ; \mathrm{TLI}=0.982 ; \mathrm{RMSEA}=0,08)$ ölçeğin yapısal geçerliliğinin kabul edilebilir düzeyde olduğunu göstermektedir (14). 


\section{Anlamsal Farklılık Ölçeği-Anne Olarak Ben}

Bu ölçek, "anne olarak kendim” kavramının değerlendirilme boyutlarını ölçer. Ölçek 11 maddeli, yedi puanlı anlamsal 11 zıt sıfat çiftinden oluşmuş olup bu 11 madde de ölçekteki 22 maddeli zıt sıfat çifti içerisine dağıtılmıştır. Ölçeğin geçerlilik güvenilirlik çalışmasında Cronbach Alfa iç tutarlılık katsayısı 0.73-0.74 arasında bulunmuştur. Toplam puanın fazla olması olumlu annelik öz değerlendirmesini göstermektedir (11). Ölçeğin bu araştırmadaki Cronbach Alfa iç tutarlılık katsayısı 0.82 olarak bulunmuştur. Uyum iyiliği değerleri ( $\mathrm{N}=368$ için; $\chi 2 / \mathrm{Sd}=3.581 ; \mathrm{GFI}=0.955 ; \mathrm{CFI}=0.953 ; \mathrm{TLI}=0.923$; RMSEA=0,08) ölçeğin yapısal geçerliliğinin kabul edilebilir düzeyde olduğunu göstermektedir (14).

\section{Anlamsal Farklılık Ölçeği-Bebeğim}

Bu ölçek, "bebeğim” kavramının değerlendirilme boyutlarını ölçer. Ölçek altı maddeli, yedi puanlı anlamsal altı zıt sıfat çiftinden oluşmakta olup bu altı madde, ölçekteki 21 maddeli zıt sıfat çifti içerisine dağıtılmıştır. Ölçeğin geçerlilik güvenilirlik çalışmasında Cronbach Alfa iç tutarlılık katsayısı 0.54-0.55 arasında bulunmuştur. Alınan toplam puanın fazla olması olumlu bebeğim değerlendirmesini göstermektedir (11). Ölçeğin bu araştırmadaki Cronbach Alfa iç tutarlılık katsayısı 0.71 olarak bulunmuştur. Uyum iyiliği değerleri $(\mathrm{N}=368$ için; $\chi 2 / \mathrm{Sd}=0.772 ; \mathrm{GFI}=0.998 ; \mathrm{CFI}=1.00 ; \mathrm{TLI}=1.00 ; \mathrm{RMSEA}=0,00)$ ölçeğin yapısal geçerliliğinin kabul edilebilir düzeyde olduğunu göstermektedir (14).

\section{Verilerin Toplanması}

Veriler vajinal yoldan ya da sezaryen ile doğum yapan ve doğumdan sonra 24-72 saat içinde hastanede yatan annelerden toplanmıştır. Veri toplama araçları annelerin tercihine göre kendileri tarafından ya da araştırmacı tarafından yüz yüze görüşme tekniği ile doldurulmuştur. Annelerin, veri toplama araçlarını kendi doldurmak istediği durumlarda araştırmacı annelerin yanında kalarak anlaşılmayan noktalarda açıklamalarda bulunmuştur. Bir anket formunun doldurulma süresi yaklaşık 20 dakika sürmüştür.

\section{Verilerin Analizi}

Verilerin analizinde SPSS 22.0 ve AMOS 21.0 (ölçeklerin doğrulayıcı faktör analizinde) paket programları kullanılmıştır. Araştırmada örneklemi oluşturan bireylerin demografik özelliklerinin analizinde tanılayıcı istatistiklerden frekans ve yüzde kullanılmıştır. Sürekli değişkenlerin analizinde aritmetik ortalama, standart sapma, minimum ve maksimum puanlar kullanılmıştır. Araştırmada kullanılacak diğer istatistiklerin belirlenmesi amacıyla puanların normal dağılıp dağılmadığının belirlenmesi için Kolmogrow-Smirnov (K-S) testi, çarpıklık (skewness) ve basıklık (kurtosis) katsayıları incelenmiştir. Araştırmada iki grubun ortalamalarının karşılaştırılmasında bağımsız gruplar t testi, ikiden fazla grubun ortalamalarının karşılaştırılmasında ise tek yönlü varyans analizi (ANOVA) kullanılmıştır. ANOVA' da gruplar arasındaki farklılaşmanın kaynağının belirlenmesinde Post Hoc testlerinden Tukey testi kullanılmıştır. Ancak gruplar arası karşılaştırmalarda gruplardaki örneklem sayısı düşük olan durumlarda nonparametrik karşılığı olan Mann Whitney U testi ve Kruskal Wallis H testi kullanılmıştır. Kruskall Wallis H testi için post hoc testleri bulunmadığı için gruplar arasındaki farklılaşmanın kaynağı Mann Whitney U testi ile incelenmiştir. Araştırmanın değişkenleri 
arasındaki ilişkinin belirlenmesinde Pearson Momentler Çarpımı Korelasyonu, bağımsız değişkenlerin bağımlı değişken üzerindeki etkisinin (açıklama/yordama gücü) incelenmesinde ise çoklu regresyon analizi stepwise metodu kullanılmıştır. Çoklu regresyon analizi varsayımları; (a) yordayıcı değişkenlerin her birisinin yordanan değişkenle arasında doğrusal bağlantı olması (doğrusallık), (b) bağımsız değişkenler arasında yüksek düzeyde korelasyonolmaması (çoklu bağlantılık), (c) otokorelasyonun (hatalardan bağımsızlık) olmaması işlemleri için şu işlemler yapılmıştır: bağımsız değişkenler arasındaki 0.80'in üzerindeki yükssek ilişki durumu bir bağımsız değişkenin diğerinin gücünü zayıflatmakta ve çoklu bağlantılılık sorunu oluşturabilmektedir. Bu araştırmada bağımsız değişkenler arasındaki en yüksek ilişki 0.55 düzeyinde bulunmuştur. Ayrıca varyans büyütme faktörü (VarianceİnflationFactor-VIF) değerinin 10'dan yüksek olmasının, bir bağımsız değişkenle ilgili olarak diğer bağımsız değişkenlerin açıklayamadıkları varyans olan Tolerans değerinin (1-R2) 0.20'den düşük olmasının ve durum indeks (Conditionindices-CI) değerinin 30'dan yüksek çıkması durumunun da çoklu bağlantı sorununa işaret ettiği belirtilmektedir (16). Bu araştırmada maksimum VIF değeri 1.528'dir. Minimum tolerans değeri 0.654 olarak; durum indeksi maksimum değeri 20.649 olarak bulunmuştur. Bu değerler bağımsız değişkenler arasında çoklu bağlantılılık sorunu olmadığını göstermektedir. Otokorelasyonun (hataları bağımsızlığı) olmamasına ilişkin Durbin Watson katsayısı incelenmiştir. Bu katsayının 1.5-2.5 arasında olması önerilmektedir. Bu araştırmada 2.155 olarak belirlenmiştir. $\mathrm{Bu}$ değerler, puanların regresyon analizine uygun olduğunu göstermektedir. Tüm istatistiksel analizlerde 0.05 anlamlılık düzeyi olarak esas alınmıştır.

\section{BULGULAR}

Annelerin yaş ortalamasının 28.79+5.09 olduğu, yaklaşık olarak 3/4’ünün ortaöğretim ve üstü eğitim düzeyine sahip olduğu, \%95.9'unun ( $n=353)$ isteyerek evlendiği, evlilik süresi ortalamalarının 5.52+4.03 olduğu görülmektedir. Annelerin \%43.2'si (n=159) bir canlı doğum yapmış, \%78'i (n=287) son gebeliklerini isteyerek gerçekleştirmiş ve \%55.2'si (n=203) son doğumlarını normal doğumla yapmış oldukları, görülmektedir (Tablo 1).

Doğan bebeklerin \%45.1 (n=166) k1z, \%54.9'u (n=202) erkektir. Annelerin \%43.5'i (n=160) ilk 30 dakika içinde bebeği kucağına almış ve \%27.4'ü (n=101) doğumdan hemen sonra bebeklerini emzirmişlerdir. Bebeklerin \%63.3’ü $(n=233)$ anne sütü ile beslenmektedir. Bebeklerin \%26.4'ünün ( $n=97)$ doğum sonrası sağlık problemi yaşamış ve \%29.1'i $(n=107)$ kuvözde kalmıştır (Tablo 2).

Anne-bebek bağlanma düzeyinin anne eğitim, sosyal güvence, gelir durumu ve aile tipine göre farklılaştığı görülmüştür $(\mathrm{p}<0.05)$. Eğitim durumundaki farklılığın hangi gruplardan kaynaklandığını belirlemek için yapılan ileri analizde; yükseköğretim mezunu olan annelerin, ilkokul ve ortaokul mezunu annelere göre anne-bebek bağlanma düzeylerinin yüksek olduğu belirlenmiştir. Gelir durumuna ait farklılığın ise, gelir durumu algısı iyi olan annelerin, gelir durumu alg1sı orta ve kötü olan annelere göre anne-bebek bağlanma düzeyinin yüksek olduğu tespit edilmiştir. Sosyal güvencesi olan ve çekirdek aile olarak yaşayan annelerin anne-bebek bağlanma düzeylerinin de sosyal güvencesi olmayan ve geniş aile yapısında olan annelerden daha yüksek olduğu saptanmıştır (Tablo 3).

Anne-bebek bağlanma düzeyinin isteğe bağlı evlilik, canlı doğum sayısı, gebeliğin isteğe bağlı olması, doğum şekli ve doğum öncesi bakım eğitimi alma değişkenlerine göre 
farklılaştığ1 görülmektedir ( $\mathrm{p}<0.05)$. Evliliği ve gebeliği isteğe bağlı olan, normal doğum yapan, doğum öncesi bakım alan annelerin anne-bebek bağlanma düzeylerinin diğer gruplara göre daha yüksek olduğu tespit edilmiştir.

Tablo 1. Anneleri Tanımlayıcı ve Doğurganlığa İlişkin Özellikleri (n=368)

\begin{tabular}{|c|c|c|c|}
\hline Değişkenler & Kategoriler & $n$ & $\%$ \\
\hline Anne yaș & Ort \pm SS & \multicolumn{2}{|c|}{$28.79 \pm 5.09$} \\
\hline \multirow{4}{*}{ Anne eğitim durumu } & İlkokul & 45 & 12.2 \\
\hline & Ortaokul & 58 & 15.8 \\
\hline & Lise ve dengi & 112 & 30.4 \\
\hline & Yükseköğretim & 153 & 41.6 \\
\hline Baba yaș & Ort \pm SS & \multicolumn{2}{|c|}{$31.59 \pm 5.47$} \\
\hline \multirow{4}{*}{ Baba Eğitim Durumu } & İlkokul & 39 & 10.6 \\
\hline & Ortaokul & 47 & 12.8 \\
\hline & Lise ve dengi & 126 & 34.2 \\
\hline & Yükseköğretim & 156 & 42.4 \\
\hline \multirow{2}{*}{ Sosyal güvence } & Var & 341 & 92.7 \\
\hline & Yok & 27 & 7.3 \\
\hline \multirow{3}{*}{ Gelir durumu } & İyi & 108 & 29.3 \\
\hline & Orta & 234 & 63.6 \\
\hline & Kötü & 26 & 7.1 \\
\hline \multirow{2}{*}{ Aile tipi } & Çekirdek & 275 & 74.7 \\
\hline & Geniş & 93 & 25.3 \\
\hline \multirow{2}{*}{ İsteyerek evlenme } & Evet & 353 & 95.9 \\
\hline & Hayır & 15 & 4.1 \\
\hline Evlilik süresi & Ort \pm SS & \multicolumn{2}{|c|}{$5.52 \pm 4.03$} \\
\hline \multirow{4}{*}{ Canlı doğum sayısı } & 1 & 159 & 43.2 \\
\hline & 2 & 105 & 28.5 \\
\hline & 3 & 78 & 21.2 \\
\hline & 4 ve $\uparrow$ & 26 & 7.1 \\
\hline \multirow{2}{*}{ Gebeliği isteme } & Evet & 287 & 78 \\
\hline & Hayır & 81 & 22 \\
\hline \multirow{2}{*}{ Son doğum şekli } & Normal & 203 & 55.2 \\
\hline & Sezaryen & 165 & 44.8 \\
\hline
\end{tabular}

Tablo 2. Bebeklerin Tanımlayıcı Özellikleri ( $\mathrm{n}=368)$

\begin{tabular}{cccc}
\hline Değişkenler & Kategoriler & $\boldsymbol{n}$ & $\mathbf{\%}$ \\
\hline \multirow{2}{*}{ Bebeğin cinsiyeti } & Kız & 166 & 45.1 \\
& Erkek & 202 & 54.9 \\
\hline Bebeği kucağa ilk alma & İlk 30 dak & 160 & 43.5 \\
& 31. dak. sonra & 208 & 56.5 \\
\hline \multirow{2}{*}{ Illk emzirme } & Hemen & 101 & 27.4 \\
& $1-2$ saat içinde & 196 & 53.3 \\
& 3-4 saat içinde & 51 & 13.9 \\
& 4 saat sonrası & 10 & 2.7 \\
Bebeği besleme & Emzirmedi & 10 & 2.7 \\
\hline \multirow{2}{*}{ Bebeğin kuvözde kalması } & Anne sütü & 233 & 63.3 \\
Bebeğin doğum sonrası sağlık & Anne sütü ve hazır mama/Ek gida & 135 & 36.7 \\
problemi & Evet & 107 & 29.1 \\
& Hayır & 261 & 70.9 \\
\hline
\end{tabular}


Canlı doğum sayısındaki farkın hangi gruplar arasında olduğunu belirlemek için yapılan ileri analiz sonucuna göre, bir canlı doğum gerçekleştiren annelerin anne-bebek bağlanma düzeyleri iki, üç ve dört canlı doğum gerçekleştiren annelerden daha yüksek olduğu belirlenmiştir. İki ve üç canlı doğum gerçekleştiren annelerin dört ve üstü canlı doğum gerçekleştiren annelerden anne-bebek bağlanma düzeyi daha yüksektir. Canlı doğum sayısı arttıkça anne-bebek bağlanma düzeyinde azalma olduğu görülmektedir (Tablo 3).

Tablo 3. Anne-Bebek Bağlanma Düzeyinin Anneye Ait Bazı Değişkenlere, Evlilik ve Gebelik Özelliklerine Göre Karşılaştırılması $(n=368)$

\begin{tabular}{|c|c|c|c|c|c|c|}
\hline & Alt Değişkenler & n & Ort. & SS. & $\mathbf{F}$ & p (fark) \\
\hline \multirow{4}{*}{ Eğitimdurumu* } & İlkokul (1) & 45 & 20.77 & 2.25 & 12.987 & 0.000 \\
\hline & Ortaokul (2) & 58 & 21.93 & 2.05 & & $(4>1,2)$ \\
\hline & Lisevedengi (3) & 112 & 22.31 & 2.24 & & $(3,2>1)$ \\
\hline & Yükseköğretim (4) & 153 & 22.75 & 1.44 & & \\
\hline \multirow{3}{*}{ Gelirdurumu* } & İyi (1) & 108 & 22.83 & 1.46 & 14.337 & 0.000 \\
\hline & Orta (2) & 234 & 22.16 & 2.08 & & $(1>2,3)$ \\
\hline & Kötü (3) & 26 & 20.61 & 2.33 & & $(2>3)$ \\
\hline \multirow{4}{*}{ Canlıdoğum* } & doğum (1) & 159 & 23.01 & 1.56 & 27.120 & 0.000 \\
\hline & 2 doğum (2) & 105 & 22.12 & 1.90 & & $1>2,3,4$ \\
\hline & 3 doğum (3) & 78 & 21.16 & 2.14 & & $2,3>4$ \\
\hline & 4 veüstüdoğum (4) & 26 & 19.84 & 1.91 & & \\
\hline \multirow{6}{*}{ Emzirmezamanı* } & Hemen (1) & 101 & 22.86 & 1.72 & 4.284 & 0.001 \\
\hline & 1-2 saatiçinde (2) & 196 & 22.15 & 1.97 & & $1>2,3,4,5$ \\
\hline & 3-4 saatiçinde (3) & 51 & 21.68 & 2.31 & & \\
\hline & 4 saattensonra (4) & 10 & 21.30 & 2.58 & & \\
\hline & Emzir(e)medim (5) & 10 & 21.80 & 1.81 & & \\
\hline & Alt Değişkenler & $\mathbf{n}$ & Ort. & SS. & $\mathbf{t}$ & $\begin{array}{c}\mathbf{p} \\
\text { (fark) }\end{array}$ \\
\hline \multirow{2}{*}{ Sosyalgüvence ${ }^{* *}$} & Var & 341 & 22.36 & 1.92 & 3.823 & 0.000 \\
\hline & Yok & 27 & 20.85 & 2.55 & & \\
\hline \multirow{2}{*}{ Aile tipi ${ }^{* *}$} & Çekirdekaile & 275 & 22.66 & 1.70 & 7.285 & 0.000 \\
\hline & GenişAile & 93 & 21.02 & 2.32 & & \\
\hline \multirow{2}{*}{ İsteğebağlıevlilik ${ }^{* *}$} & Evet & 353 & 22.37 & 1.93 & 722.500 & 0.000 \\
\hline & Hayır & 15 & 19.40 & 1.76 & & \\
\hline \multirow{2}{*}{ İsteğebağlıgebelik** } & Evet & 287 & 22.79 & 1.54 & 11.456 & 0.000 \\
\hline & Hayır & 81 & 20.30 & 2.25 & & \\
\hline \multirow{2}{*}{ Doğumşekli*** } & Normal & 203 & 22.54 & 1.80 & 3.180 & 0.002 \\
\hline & Sezaryen & 165 & 21.88 & 2.18 & & \\
\hline \multirow{2}{*}{ Bakımeğitimi alma** } & Evet & 311 & 22.40 & 2.30 & 3.587 & 0.000 \\
\hline & Hayır & 57 & 21.38 & 2.20 & & \\
\hline \multirow{2}{*}{ Bebeğincinsiyeti** $^{* *}$} & $\mathrm{~K} 1 \mathrm{z}$ & 166 & 22.37 & 1.87 & 1.121 & 0.000 \\
\hline & Erkek & 202 & 21.14 & 2.10 & & \\
\hline \multirow{2}{*}{ Kucağaalınmazamanı** } & İlk $30 \mathrm{dk}$ & 160 & 22.68 & 1.73 & 3.670 & 0.000 \\
\hline & 31. Dksonra & 208 & 21.91 & 2.14 & & \\
\hline \multirow{2}{*}{ Beslenmetürü̈* $^{* *}$} & Anne sütü & 233 & 22.45 & 1.83 & 2.589 & 0.010 \\
\hline & Anne sütü/Hazır mama/Ekgıda & 135 & 21.89 & 2.25 & & \\
\hline \multirow{2}{*}{ Kuvözdekalma ${ }^{* *}$} & Evet & 107 & 21.70 & 2.32 & -3.403 & 0.001 \\
\hline & Hayır & 261 & 22.47 & 1.82 & & \\
\hline \multirow{2}{*}{$\begin{array}{l}\text { Sağlık problem } \\
\text { yaşama** }\end{array}$} & Evet & 97 & 21.71 & 2.18 & -3.112 & 0.002 \\
\hline & Hayır & 271 & 22.44 & 1.90 & & \\
\hline
\end{tabular}

${ }^{*}$ Tek yönlü varyans analizi (Anova), ${ }^{* *}$ Bağımsız gruplar için t testi 
Anne-bebek bağlanma düzeyinin bebeğin cinsiyeti, bebeğin kucağa alınma ve emzirilme zamanı, beslenme türü, kuvözde kalma ve sağlık problemi yaşama durumlarına göre farklılaştığı saptanmıştır ( $<$ <0.05). Kız çocuğu olan, ilk 30 dakika içinde bebeklerini kucağına alan, sadece anne sütü ile beslenen, bebeği sağlık sorunu yaşamayan ve kuvözde kalmayan annelerin anne-bebek bağlanma düzeylerinin diğer gruplara göre daha yüksek olduğu belirlenmiştir. İlk emzirilme zamanına göre farklılığın bebeğini doğumdan hemen sonra emziren annelerin anne-bebek bağlanma düzeylerinin diğer gruptaki annelerden yüksek olmasından kaynaklandığı belirlenmiştir (Tablo 3).

Anne-bebek bağlanma, algılanan sosyal destek, anlamsal farklılık-anne olarak ben ve anlamsal farklılık bebeğim değişkenleri arasındaki ilişkinin belirlenmesi için Pearson Momentler Çarpımı Korelasyonu Katsayısı kullanılmıştır. Anne-bebek bağlanma düzeyi ile algılanan sosyal destek arasında $\mathrm{r}=0.40$ düzeyinde pozitif, anlamlı ve orta düzeyde ilişki bulunmuştur. Sosyal destek algısı alt boyutları ile anne-bebek bağlanma düzeyi arasındaki korelasyon değerleri incelendiğinde aile alt boyutu ile ( $\mathrm{p}=0.001 ; \mathrm{r}=0.47)$; arkadaş alt boyutu ile $\mathrm{r}=0.36$; yakın insan alt boyutu ile $\mathrm{r}=0.29$ düzeyinde pozitif ve anlamlı ilişki bulunmuştur. Annebebek bağlanma düzeyi ile annenin annelik algısı (anne olarak ben) arasındaki ilişki incelendiğinde $\mathrm{r}=0.54$ düzeyinde pozitif orta düzeyde ilişki bulunmuştur. Buna göre annelerin anneliğe ilişkin anlamsal farklılık (anne olarak ben) düzeyleri arttıkça anne-bebek bağlanma düzeylerinde anlamlı bir artışın meydana gelebileceği söylenebilir. Anne-bebek bağlanma düzeyi ile annenin bebeğine ilişkin anlamsal farklılık düzeyi arasında $r=0.33$ düzeyinde pozitif, anlamlı ve orta düzeyde ilişki bulunmuştur. Buna göre annelerin bebeklerine ilişkin olumlu algıları arttıkça anne-bebek bağlanma düzeylerinde anlamlı bir artışın meydana gelebileceği söylenebilir (Tablo 4).

Tablo 4. Değişkenler Arası Korelasyon Değerleri ( $\mathrm{n}=368)$

\begin{tabular}{|c|c|c|c|c|c|c|c|c|c|}
\hline & Ort. & SS. & (1) & (2) & $(2-1)$ & $(2-2)$ & $\overline{(2-3)}$ & (3) & (4) \\
\hline $\begin{array}{c}\text { Anne-Bebek Bağlanma } \\
\text { (1) }\end{array}$ & $\begin{array}{c}22.2 \\
5\end{array}$ & 2.01 & 1.00 & & & & & & \\
\hline $\begin{array}{l}\text { Algılanan Sosyal Destek } \\
\text { (2) }\end{array}$ & $\begin{array}{c}62.7 \\
2\end{array}$ & $\begin{array}{c}16.1 \\
5\end{array}$ & $0.40^{*}$ & 1.00 & & & & & \\
\hline Aile (2-1) & $\begin{array}{c}23.7 \\
1\end{array}$ & 5.06 & $0.47^{*}$ & $0.80 *$ & 1.00 & & & & \\
\hline Arkadaş (2-2) & $\begin{array}{c}20.0 \\
2\end{array}$ & 6.28 & $0.36^{*}$ & $0.93 *$ & $0.61 *$ & 1.00 & & & \\
\hline Yakın İnsan (2-3) & $\begin{array}{c}18.9 \\
8\end{array}$ & 6.67 & $0.29 *$ & $0.94 *$ & $0.60 *$ & $0.86^{*}$ & 1.00 & & \\
\hline $\begin{array}{l}\text { Anlamsal Farklıık- } \\
\text { Anne Olarak Ben (3) }\end{array}$ & $\begin{array}{c}51.2 \\
3\end{array}$ & 7.31 & $0.54 *$ & $0.27 *$ & $0.23 *$ & $0.35^{*}$ & $0.16^{*}$ & 1.00 & \\
\hline $\begin{array}{l}\text { Anlamsal Farklılık - } \\
\text { Bebeğim (4) }\end{array}$ & $\begin{array}{c}22.8 \\
8\end{array}$ & 3.92 & $0.33^{*}$ & -0.04 & 0.01 & 0.04 & $-0.14 *$ & $\begin{array}{c}0.55 \\
*\end{array}$ & $\begin{array}{c}1.0 \\
0\end{array}$ \\
\hline
\end{tabular}

Araştırmada annelerin sosyal destek algısı (aile, arkadaş, yakın insan), annelik algısı (anlamsal farklılık-anne olarak ben) ve bebek algısının (anlamsal farklılık-bebeğim) annebebek bağlanma düzeyi üzerindeki etkisinin (açıklama/yordama gücü) incelenmesi için çoklu regresyon analizi yapılmıştır. Bu doğrultuda sosyal destek algısı alt boyutları olan aile, arkadaş ve yakın insan ile anlamsal farklılık-anne olarak ben ölçek puanları ve anlamsal farklılık- 
bebeğim ölçek puanları bağımsız değişkenler olarak belirlenirken, anne-bebek bağlanma ölçek puanları ise bağımlı değişken olarak belirlenmiştir. Anne-bebek bağlanma düzeyinin \%42.3'ü anlamsal farklılık-anne olarak ben, sosyal destek algısı (aile) ve anlamsal farklılık bebeğim puanları tarafından açıklanmaktadır (yordanmaktadır) (Tablo 5).

Tablo 5. Annelerin Anlamsal Farklılık-Anne Olarak Ben, Anlamsal Farklılık Bebeğim ve Sosyal Destek Algılarının Anne Bebek Bağlanma Düzeyine Etkisi

\begin{tabular}{|c|c|c|c|c|c|c|c|}
\hline $\begin{array}{l}\text { Bağımlı } \\
\text { Değişken }\end{array}$ & Bağımsız Değişkenler & St. Beta & $\mathbf{t}$ & $\mathbf{p}$ & $\mathbf{R}^{2}$ & Düz. $\mathbf{R}^{2}$ & $\mathbf{F}$ \\
\hline \multirow{2}{*}{$\begin{array}{c}\text { Model 1 } \\
\text { Anne Bebek } \\
\text { Bağlanma } \\
\end{array}$} & Sabit & & 23.410 & 0.000 & \multirow[t]{2}{*}{0.288} & \multirow[t]{2}{*}{0.286} & \multirow[t]{2}{*}{$\overline{148.086}$} \\
\hline & $\begin{array}{c}\text { Anlamsal Farklılık- } \\
\text { Anne Olarak Ben }\end{array}$ & 0.537 & 12.169 & 0.000 & & & \\
\hline \multirow{3}{*}{$\begin{array}{c}\text { Model 2 } \\
\text { Anne Bebek } \\
\text { Bağlanma }\end{array}$} & Sabit & & 19.866 & 0.000 & \multirow[t]{3}{*}{0.419} & \multirow[t]{3}{*}{0.415} & \multirow[t]{3}{*}{$\begin{array}{c}131.34 \\
5\end{array}$} \\
\hline & $\begin{array}{l}\text { Anlamsal Farkl111k- } \\
\text { Anne Olarak Ben }\end{array}$ & 0.453 & 11.063 & 0.000 & & & \\
\hline & Sosyal Destek (Aile) & 0.371 & 9.049 & 0.000 & & & \\
\hline \multirow{4}{*}{$\begin{array}{c}\text { Model 3 } \\
\text { Anne Bebek } \\
\text { Bağlanma }\end{array}$} & Sabit & & 17.927 & 0.000 & \multirow[t]{4}{*}{0.428} & \multirow[t]{4}{*}{0.423} & \multirow[t]{4}{*}{90.609} \\
\hline & $\begin{array}{l}\text { Anlamsal Farklılık- } \\
\text { Anne Olarak Ben }\end{array}$ & 0.388 & 7.911 & 0.000 & & & \\
\hline & Sosyal Destek (Aile) & 0.384 & 9.352 & 0.000 & & & \\
\hline & $\begin{array}{c}\text { Anlamsal Farklılık- } \\
\text { Bebeğim }\end{array}$ & 0.114 & 2.394 & 0.017 & & & \\
\hline
\end{tabular}

\section{TARTIŞMA}

Doğumdan sonraki süreçte anne ile bebeğin bağlanmasının erken dönemde başlatılması bebeğin daha sonraki gelişim dönemlerini de olumlu yönde etkilemektedir. Doğumdan hemen sonra annenin bebeği ile bir araya gelmesi, bebeğini kucaklaması ve emzirmesi bağlanma sürecinin ilk aşamalarındandır (4). Anne bebek bağlanması anneye ve bebeğe ait birçok değişkenden etkilenmektedir.

Çalışmada anneye ait tanımlayıcı özelliklerden eğitim durumuna bağlı olarak annebebek bağlanma düzeyinde artış olduğu; eğitim durumu arttıkça bağlanma düzeyinin de arttığı görülmüştür. Yapılan çalışmalarda anne-bebek bağlanma düzeyi ile anne eğitim durumu arasında farklı sonuçlar elde edilmiştir (17-20). Bazı çalışmalarda yapılan çalışmaya benzer şekilde eğitim durumu arttıkça bağlanma düzeyinin de arttığ belirlenirken $(17,18)$; bazı çalışmalarda ise anne eğitim durumunun anne bebek bağlanmasını etkilemediği belirlenmiştir $(19,20)$. Eğitim düzeyinin yükselmesi ile annelerin bebek bakımı konusunda daha fazla bilgiye ulaşabilmesi mümkün olduğundan anne-bebek bağlanma düzeyinin de yüksek olabileceği düşünülmektedir.

Anne-bebek bağlanma düzeyinin annenin sosyal güvence sahip olma ve gelir durumuna göre farklılaştığı; sosyal güvenceye sahip olan ve gelir durumu yüksek olan annelerin bağlanma düzeylerinin daha yüksek olduğu tespit edilmiştir. Yapılan çalışmalarda da benzer şekilde sosyal güvencesi (18) ve gelir durumu iyi olan (21) annelerin anne-bebek bağlanma düzeyinin yüksek olduğu tespit edilmiştir. Annenin sosyal güvencesinin ve gelir durumunun bağlanma düzeyini etkilemesi beklendik bir bulgudur. Annenin sosyal güvencesinin olmaması ve ekonomik sorunlarının olması gelecekle ilgili kaygılarının artması nedeniyle bağlanmayı olumsuz etkileyebileceği düşünülmektedir. 
Anne-bebek bağlanma düzeyinin aile tipine göre farklılaştığı, çekirdek aile olarak yaşayan annelerin, anne-bebek bağlanma düzeyleri geniş aile olarak yaşayana ailelere göre daha yüksek olduğu belirlenmiştir. Şolt Kırca ve Savaşer ise çalışmalarında, aile tipinin annebebek bağlanma düzeyini etkilemediğini bildirmiştir (20). Çekirdek ailelerde anneler bebeğinin bakımını kendi yerine getirirken aynı zamanda bebeği ile daha çok baş başa kalabilmektedir. Ancak geniş ailelerde genelde bebeğin bakımında aile büyüklerinin etkili olmasının, annenin bebeği ile daha az vakit geçirmesinin ve bebeğinin bakımına daha az katılmasının bu durumda etkili olabileceği düşünülmektedir.

Anne-bebek bağlanma düzeyinin isteğe bağlı evlilik değişkenine göre farklılaştı̆̆ı, isteğe bağlı evlilik gerçekleştiren annelerin anne-bebek bağlanma düzeylerinin daha yüksek olduğu tespit edilmiştir. Lerum ve LoBiondo-Wood çalışmaya benzer sonuçlar elde etmiştir (22). Annenin kendi isteği ve istediği kişiyle evlenmesi nedeniyle daha mutlu olmasının bebeği ile bağlanmasını da olumlu etkilemiş olabileceği düşünülmektedir.

Anne-bebek bağlanma düzeyinin annenin canlı doğum sayısına göre farklılaştığı, canlı doğum sayısındaki artışa bağlı olarak anne-bebek bağlanma düzeyinde azalma olduğu belirlenmiştir. Araştırma bulgularını destekler şekilde Mutlu ve ark. ilk kez çocuğu olan annelerin iki veya daha fazla çocuğu olan annelere göre bağlanma düzeyinin daha yüksek olduğunu belirtmiştir (10). Bu durumun annenin çocuk sayısı arttıkça bakım vereceği kişi sayısı arttığından bağlanma düzeyinin azalmasının olağan bir durum olduğu düşünülmektedir.

Anne-bebek bağlanma düzeyinin isteğe bağlı gebelik değişkenine göre farklılaştı̆̆ isteğe bağlı gebelik gerçekleştiren annelerin anne-bebek bağlanma düzeylerinin daha yüksek olduğu tespit edilmiştir. Yapılan bir çalışmada da araştırma bulgusunu destekler şekilde gebeliğin planlı olması durumunda bağlanmanın yüksek olduğu belirtilirken (23); bazı çalışmalarda ise bu durumun anne bebek bağlanmasını etkilemediği belirtilmiştir $(21,24)$. Annelerin çocuklarını planladıkları zaman diliminde isteyerek dünyaya getirmesinin bebeği her yönden kabullenerek annelik rolüne hazır olmayı ve anne-bebek bağlanma düzeyini arttıracağı düşünülmektedir.

Anne-bebek bağlanma düzeyinin doğum yöntemi değişkenine göre farklılaştığı, normal doğum gerçekleştiren annelerin anne-bebek bağlanma düzeylerinin, sezaryen ile doğum gerçekleştiren annelere göre daha yüksek olduğu belirlenmiştir. Yapılan bazı çalışmalarda araştırma bulgusunu destekler şekilde vajinal yoldan doğum yapan annelerin bağlanma düzeylerinin sezaryen ile doğum yapan annelere göre daha yüksek olduğu tespit edilirken $(19,25)$; bazı çalışmalarda ise doğum şeklinin bağlanmayı etkilemediği tespit edilmiştir $(24,26)$. Normal doğum yapan annelerin bebeklerini daha erken dönemde görebilmesinin bağlanmayı olumlu etkilediği, sezaryen ile doğum gerçekleştiren annelerin ise ağrısının olması, fiziksel olarak kısıtlı olması ve bebeklerini daha geç görmelerinin bağlanmayı olumsuz etkileyebileceği belirtilmektedir (27). Normal doğum yapan annelerin bağlanma düzeyinin yüksek olması beklendik bir bulgudur. Vajinal yoldan gerçekleşen doğumlarda annenin bebeği ile erken dönemde teması sağlanıp, emzirme süreci erken dönemde başlatıldığından sezaryen ile doğum yapan annelere göre bağlanma düzeyinin daha yüksek olduğu düşünülmektedir.

Anne-bebek bağlanma düzeyinin bebeğin kucaklanma zamanına göre farklılaştığı, ilk 30 dakika içinde bebeklerini kucaklayan annelerin anne-bebek bağlanma düzeylerinin daha yüksek olduğu tespit edilmiştir. Mutlu ve ark. (10), Çakır ve Alparslan (27)'ın yaptıkları çalışmalarda, bebeğini kucaklayarak ten tene temas içinde olan annelerin bağlanma 
düzeylerinin daha yüksek olduğu belirtilmiştir. Anne-bebek bağlanmasının doğumdan hemen sonra başlatılabilmesi için anne ile bebeğin en kısa zamanda bir araya gelip temasının sağlanmasının gerektiği düşünülmektedir.

Anne-bebek bağlanma düzeyinin bebeğin ilk emzirilme zamanına göre farklılaştı̆̆ı, doğumdan hemen sonra emziren annelerin diğer gruptaki (1-2 saat içinde emziren, 3-4 saat içinde emziren, 4 saatten sonra emziren ve emziremeyen) annelerden anne-bebek bağlanma düzeylerinin yüksek olduğu belirlenmiştir. Ancak bazı çalışmalarda ilk emzirilme zamanının annelerin bağlanma düzeyine etkisi olmadığ 1 ifade edilmiştir (19,24). Bağlanma sürecinde emzirme önemli bir faktör olduğundan doğumdan sonra bebeğini en kısa sürede emziren annelerin bebeği ile aralarındaki bağlanmanın olumlu etkilenmesi beklendik bir bulgudur.

Anne-bebek bağlanma düzeyinin bebeğin beslenme türüne göre farklılaştığ ile beslenen bebeklerin annelerinin anne-bebek bağlanma düzeylerinin, anne sütü yanında hazır mama ve ek gidalarla beslenen bebeklerin annelerinin anne-bebek bağlanma düzeylerinden daha yüksek olduğu tespit edilmiştir. Literatür incelendiğinde bebeği anne sütü ile beslenen annelerin bağlanma düzeylerinin daha fazla olduğunu tespit edilmiştir $(18,28)$. Anne sütü alan bebeklerde emzirme zamanları anne ve bebek için çok özel anlardır. Bu süreçte anne bebeği ile baş başa kalmakta ve hem anne hem bebek doyum yaşamaktadır. Bu sebeplerden dolayı anne sütü alan bebeklerin anne-bebek bağlanma düzeyinin yüksek olması beklendik bir bulgudur.

Anne-bebek bağlanma düzeyinin bebeğin doğum sonrası sağlık problemi yaşamasına ve kuvözde kalma durumuna göre farklılaştığı, bebeği sağlık problemi yaşayan ve kuvözde kalan annelerin anne-bebek bağlanma düzeylerinin daha düşük olduğu tespit edilmiştir. Bulgularımızı destekler şekilde Wigert ve ark. (29), çalışmalarında, bebeğin hastanede kalmasının bağlanmayı olumsuz etkilediğini belirtmiştir. Anne-bebek bağlanmasında annenin bebeği ile erken dönemde temasa geçmesi istendik bir durumdur. Ancak sağlik sorunu yaşayan ya da bebeği kuvözde olan anneler bebekleri ile erken dönemde temasa geçmeyebilmektedir. Yapılan çalışmada annelerin bebeklerinin sağlık sorunu nedeniyle kuvöze alınmalarının annebebek bağlanma düzeyini olumsuz etkileyebileceği düşünülmektedir.

Anne-bebek bağlanma düzeyinin doğum öncesi bakım eğitimi alma değişkenlerine göre farklılaştığı, bakım eğitimi alan annelerin anne-bebek bağlanma düzeylerinin, almayan annelere göre daha yüksek olduğu görülmüştür. Yapılan çalışmalarda bakım eğitimi alan annelerin bağlanma düzeylerinin daha yüksek olduğu belirtilmiştir $(18,30)$. Bebeğin bakımına yönelik eğitim alan annelerin anne-bebek bağlanma düzeylerinin yüksek olmasının annelerin bebeklerinin bakımında kendilerine güvenmelerine ve kaygı yaşamamalarına bağlı olabileceği düşünülmektedir.

Anne-bebek bağlanma düzeyi ile algılanan sosyal destek arasında pozitif, anlamlı ve orta düzeyde ilişki bulunmuştur. Buna göre annelerin sosyal destek algısı arttıkça anne-bebek bağlanma düzeyinde anlamlı bir artışın meydana geleceği söylenebilir. Yapılan çalışmalarda da annenin sosyal destek sistemlerinin iyi olmasının bağlanma düzeyini arttırdığını, annenin çevresinden destek alarak iş yükünün biraz da olsa hafiflemesi, dinlenip kendine vakit ayırabilmesi ile daha huzurlu ve mutlu olduğu belirtilmektedir $(19,21,25)$.

Anne-bebek bağlanma düzeyi ile annenin, annelik algısı ve bebeğine ilişkin anlamsal farklılık düzeyi arasında pozitif orta düzeyde ilişki bulunmuştur. Buna göre annelerin anneliğe ve bebeklerine ilişkin olumlu anlamsal farklılık düzeyleri arttıkça anne-bebek bağlanma düzeylerinde anlamlı bir artışın meydana gelebileceği söylenebilir. Yapılan çalışmalarda da 
annelik ve bebeğe ilişkin algıların oluşmasında bağlanmanın önemli bir faktör olduğu belirtilmiştir $(8,25)$.

Regresyon modeline göre anlamsal farklılık anne olarak ben, anlamsal farklılıkbebeğim ve sosyal destek algısı (aile) puanları birlikte alındığında anne-bebek bağlanma düzeyinin \%42.3'ünü açıkladığı görülmüştür. Anne-bebek bağlanması annenin yakın arkadaş ve çevreden aldığı sosyal destekten etkilemezken, annenin aileden aldığı sosyal destek, annelik ve bebeğim algısından etkilendiği tespit edilmiştir. Literatür incelendiğinde bu üç ölçeğin birbiri ile karşılaştırıldığı bir çalışmaya rastlanmamıştır.

\section{SONUÇ VE ÖNERILER}

Anne-bebek bağlanmasının annelik algısı ve bazı değişkenlere göre incelenmesi amacıyla gerçekleştirilen bu çalışmadan elde edilen sonuçlar şöyledir:

- Eğitim düzeyi yüksek, sosyal güvenceye sahip, gelir durumu iyi, çekirdek aile yapısı olan, kendi isteği ile evlenen ve gebe kalan annelerin diğer gruplardaki annelere göre anne-bebek bağlanma düzeyinin daha yüksek olduğu belirlenmiştir.

- Doğum öncesi bakım için eğitim alan, normal doğum yapan, doğumdan sonra ilk 30 dakika içinde bebeklerini kucağına alan, emziren, bebeğini anne sütü ile besleyen, bebeği sağlık sorunu olmayan ve kuvözde kalmayan annelerin diğer gruplardaki annelere göre anne-bebek bağlanma düzeyinin daha yüksek olduğu tespit edilmiştir.

- Çalışmada anne-bebek bağlanma düzeyi ile algılanan sosyal destek, annenin kendine ve bebeğine ilişkin anlamsal farklılık düzeyi arasında pozitif, anlamlı ve orta düzeyde ilişki bulunmuştur.

- Regresyon modeline göre anlamsal farklılık anne olarak ben, sosyal destek algisı (aile) ve anlamsal farklılık-bebeğim puanları birlikte alındığında anne-bebek bağlanma düzeyinin \%42.3'ünü açıkladığı belirlenmiştir.

Araştırmada elde edilen bu sonuçlar doğrultusunda;

- Sağlık profesyonellerinin özellikle hemşirelerin anne adaylarına ve eşlerine gebelik ve doğumdan sonraki süreçte destek vermesi, eğitim programları ile gebenin doğumdan sonraki fiziksel ve duygusal sürece hazırlanması,

- Sağlık profesyonellerinin bebeği kuvözde kalan annelere, bebeği ile etkili şekilde bağlanabilmesi için yeterince bilgilendirme sağlaması ve aile merkezli bakım uygulayarak bu süreci en etkili şekilde yönetmesi önerilmektedir.

\section{Araştırmanın Etik Yönü}

Araştırmanın yapılabilmesi için gerekli etik kurul (27.06.2019-611) ve kurumlardan yazılı izinler alınmıştır. Araştırmaya katılan annelerden yazılı onam alınmıştır. Ölçeklerin araştırmada kullanılabilmesi için, ölçek yazarlarından elektronik posta yoluyla izin alınmıştır.

\section{Çıkar Çatışması}

Yazarlar arasında çıkar çatışması yoktur. 


\section{KAYNAKLAR}

1. Soysal A. Ş., Bodur Ş, İşeri E, Şenol S. (2005). Bebeklik dönemindeki bağlanma sürecine genel bir bakış. Klin. Psikiyatr.Derg. 8 (2), 88-99.

2. Y1lmaz, S. D. (2013). Prenatal anne-bebek bağlanması. HEAD, 10 (3), 28-33.

3. Kavlak O, Şirin A. (2009). Maternal bağlanma ölçeğinin Türk toplumuna uyarlanması. UIBD, 6 (1), 188-202.

4. Köse, D., Çınar, N., Altınkaynak, S. (2013). Yenidoğanın anne ve baba ile bağlanma süreci. STED, 22 (6), 239-245.

5. Güleşen, A., Yıldız, D. (2013). Erken postpartum dönemde anne bebek bağlanmasının kanita dayalı uygulamalar ile incelenmesi. TAF Preventive Medicine Bulletin, 12 (2), 177-82.

6. Brandon, A. R., Pitts, S., Denton, W. H., Stringer, C. A., Evans, H. M. (2009). A history of thetheory of prenatal attachment. J Prenat Perinat Psychol Health, 23 (4), 201-229.

7. İşler, A. (2007). Prematüre bebeklerde anne-bebek ilişkisinin başlatılmasında yenidoğan hemşirelerinin rolü. Perinatoloji Dergisi, 15 (1), 1-6.

8. Çalışır H, Karaçam Z. (2011). Factors associated with parenting behavior of mothers in the early postpartum period in Turkey. Nursing \& Health Sciences, 13, 488-494.

9. Dubber, S., Reck, C., Müller, M., Gawlik, S. (2015). Postpartum bonding: the role of perinatal depression, anxiety and maternal-fetal bonding during pregnancy. Arch Womens Ment Health, 18 (2), 187-195.

10. Mutlu, C., Yorbik, Ö., Tanju, İ. A., Çelikel, F., Sezer, RG. (2015). Doğum öncesidoğum sırası ve doğum sonrası etkenlerin annenin bağlanması ile ilişkisi. Anadolu Psikiyatri Dergisi, 16, 442-450.

11. Çalışır, H. (2003). İlk kez anne olan kadınların annelik rolü başarımlarını etkileyen etmenlerin incelenmesi (Yayımlanmamış Doktora Tezi). Ege Üniversitesi Sağlık Bilimleri Enstitüsü, İzmir.

12. Karakulak, Aydemir H., Alparslan Ö. (2016). Anne-bebek bağlanma ölçeğinin Türk toplumuna uyarlanması (Aydın örneği). Journal of Contemporary Medicine, 6(3);188199.

13. Eren Balc1, M. (2018). Prematüre bebeği yenidoğan yoğun bakımda yatan annelerde anne bebek bağlanması ve ilişkili faktörler. (Yayımlanmamış Yüksek Lisans Tezi). Necmettin Erbakan Üniversitesi Sağlık Bilimleri Enstitüsü, Konya.

14. Byrne, B. M. (2010). Structural equation modeling with amos. basic concepts, applications and programming, Routledge, New York.

15. Eker, D., Arkar, H., Yaldız, H. (2001). Çok boyutlu algılanan sosyal destek ölçeğinin gözden geçirilmiş formunun faktör yapısı geçerlik ve güvenirliği. Türk Psikiyatri Dergisi, 12 (1), 17-25.

16. Can, A. (2016). SPSS ile bilimsel araştırma sürecinde nicel veri analizi. (4. Baskı) Ankara: Pegem.

17. Yahşi, G., Bayraktar, S. (2016). Bağlanma kuramı çerçevesinde doğum sırasının bağlanma stilleri üzerindeki etkisinin incelenmesi. IJSSER, 2 (1), 209-218.

18. Dayan, G. (2019). Postpartum depresyonda maternal bağlanma ve algllanan sosyal destek arasındaki ilişkinin incelenmesi. (Yayımlanmamış Yüksek Lisans Tezi). Yakın Doğu Üniversitesi Sosyal Bilimler Enstitüsü Klinik Psikoloji Anabilim Dalı, Lefkoşa.

19. Çankaya, S., Yılmaz, S. D., Can, R., Kodaz, N. D. (2017). Postpartum depresyonun maternal bağlanma üzerine etkisi. Acıbadem Üniversitesi Sağllk Bilimleri Dergisi, 4, 232-240.

20. Kırca, A. Ş. \& Savaşer, S. (2017). Doğum sayısının anne-bebek bağlanmasına etkisi. Sağllk Bilimleri ve Meslekleri Dergisi, 4(3), 236-243. 
21. Bilgin, Z. \& Ecevit Alpar, Ş. (2018). Kadınların maternal bağlanma algısı ve anneliğe ilişkin görüşleri. Sağlık Bilimleri ve Meslekleri Dergisi, 5(1), 6-15.

22. Lerum C. W. \& LoBiondo-Wood G. (1989). The relationship of maternal age, quickening and physical symptoms of pregnancy to the development of maternal-fetal attachment. Birth, 16 (1), 13-7.

23. Yılmaz S. D. \& Beji N. K. (2010). Gebelerin stresle başa çıkma, depresyon ve prenatal bağlanma düzeyleri ve bunları etkileyen faktörler. Genel Tıp Dergisi, 20 (3), 99- 108.

24. Akşit, E. (2018). Postpartum dönemdeki annelerin ruhsal durumlarının anne bebek bağlanmasına etkisinin incelenmesi. (Yayımlanmamış Yüksek Lisans Tezi). Okan Üniversitesi, Hemşirelik Anabilim Dalı, İstanbul.

25. Belk1z, Lİ. (2017). Doğum şeklinin anne bebek bă̆ı üzerine etkisinin incelenmesi. (Yayımlanmamış Yüksek Lisans Tezi). Haliç Üniversitesi Sağlık Bilimleri Enstitüsü, Hemşirelik Anabilim Dalı, İstanbul.

26. Akyüz Y. (2017). Doğum yapan kadınların maternal bağlanma ve emzirme özyeterliliği ilişkisi. (Yayımlanmamış Yüksek Lisans Tezi). Okan Üniversitesi Sağlık Bilimleri Enstitüsü, Hemşirelik Anabilim Dalı, İstanbul.

27. Çakır, D., Alparslan, Ö. (2018). Doğum tipi değişkeninin anne-bebek etkileşimi ve annenin bebeğini algılaması üzerindeki etkilerinin incelenmesi. Journal of Contemporary Medicıne, 8 (2), 139-147.

28. Alan, H., Ege, E. (2013). The influence of social support on maternal-infant attachment in Turkish Society. Journal of Anatolia Nursing and Health Sciences, 16 (4), 234-40.

29. Wigert, H., Johannson, R., Berg, M., Hellströ, A.L. (2006). Mothers' experiences of having their newborn child in a neonatal intensive care unit. Scandinavian J Caring Sciences, 20 (1), 35-41.

30. Öztürk, S., Erci, B. (2016). Postpartum dönemdeki primipar annelere loğusa ve yenidoğan bakım eğitimi maternal bağlanmayı arttırdı: Son test kontrol gruplu eğitimsel araştırma. Balıkesir Sağlık Bilimleri Dergisi, 5 (3), 129-134. 